\title{
KARAKTER AGRONOMIS TANAMAN KEDELAI (GLYCINE MAX L MERRIL) TERHADAP PEMBERIAN KOMPOS KULIT BUAH KAKAO PADA TANAH ULTISOL
}

\author{
C Tri Kusumastuti ${ }^{1)}$, Muh Kusberyunadi ${ }^{2)}$ \\ 1)Fakultas Pertanian, Jurusan Agroteknologi, Universitas PGRI Yogyakarta, JI. PGRI I No 117 \\ Sonosewu Yogyakarta, Telp (0274) 376808, email:kusumastuti@upy.com \\ ${ }^{2)}$ Fakultas Pertanian, Jurusan Agroteknologi, Universitas PGRI Yogyakarta, JI. PGRI I No 117 \\ Sonosewu Yogyakarta, Telp (0274) 376808, email:muhkusberyunadi@yahoo.co.id
}

\begin{abstract}
Abstrak
Tanah ultisol merupakan salah satu jenis tanah marginal yang berpotensi untuk dikembangkan sebagai lahan pertanian karena keberadaanya yang cukup luas. Untuk meningkatkan kandungan unsur hara dan memperbaiki sifat tanah pada tanah ultisol dapat dilakukan dengan menambahkan bahan organik. Penelitian ini bertujuan untuk mengetahui karakter agronomis tanaman kedelai terhadap pemberian kompos kulit buah kakao pada tanah ultisol. Penelitian ini telah dilakukan di Dusun Soboman, Ngestiharjo, Kasian, Bantul, Yogyakarta pada bulan Juni - Agustus 2019. Penelitian ini menggunakan Rancangan Acak Lengkap dengan faktor tunggal yaitu dosis kompos kulit buah kakao yang terdiri dari 7 aras $(0,50,100,150$, 200, 250 dan 300) g / tanaman dan diulang sebanyak tiga ulangan. Variabel yang diamati meliputi jumlah bintil akar, berat kering bintil akar, panjang akar, berat kering akar, berat segar tanaman, berat kering tanaman, jumlah polong, berat biji per tanaman dan indeks panen. Data hasil pengamatan dianalisis dengan sidik ragam pada jenjang nyata $5 \%$. Hasil penelitian menunjukkan bahwa perlakuan kompos kulit buah kakao dengan dosis 150 gram per tanaman tingkat efisiensinya lebih tinggi dan memberikan pengaruh terbaik terhadap pertumbuhan dan hasil tanaman kedelai pada tanah ultisol.
\end{abstract}

Kata kunci: Kedelai, Kompos, Tanah Ultisol

\begin{abstract}
Soil ultisol is one of the type of land marginal have developed as agricultural land known for big enough. To increased of the confusion and improve the soil ultisol can be done by adding the organic matter. The studi aimed to determinate the agronomic responses of soybean on cacao pods compost in the ultisom soil. The research conducted at Soboman, Ngestiharjo, Kasian, Bantul, Yogyakarta on June - August 2019. The study consist of one factor which are arranged in a completely randomized design (CRD) with three replication. This factor is level cacao pods compost consist of 0, 50,100, 150,200, 250 and $300 \mathrm{~g} / \mathrm{plant}$. The observed variable werw the number of nodules, nodule dry weight, long root,dry root, fresh weight plant, dry plant, number of pods, weight seed on plant and index harvest. Result of the study were analyzed using analisis of variance on the significant level of $5 \%$. The result showed that levels the cacao pods compost $150 \mathrm{~g} / \mathrm{plant}$ more than efficiency and give impact best on the growth and the results of the soybean plant on the ultisol soil.
\end{abstract}

Keywords: Soybean, Compost, Ultisol soil 


\section{PENDAHULUAN}

Kedelai merupakan tanaman pangan sumber protein nabati dengan harga terjangkau dan banyak dibutuhkan oleh masyarakat. Untuk memenuhi kebutuhan akan kedelai Indonesia masih mengimpor dari luar negeri. Kekurangan pasokan kedelai tahun 2016 - 2019 masing-masing sebesar 1,61 juta ton, 1,83 juta ton, 1,93 juta ton dan 1,93 juta ton (Riniarsi, 2015). Oleh karena itu perlu dilakukan upaya untuk meningkatkan produksi kedelai dalam negeri melalui perbaikan budidaya dan perluasan areal tanam salah satunya dengan pemanfaatan lahan marginal untuk pengembangan kedelai.

Tanah marginal merupakan tanah yang sudah mengalami proses pelapukan lanjut. Salah satu jenis tanah yang merupakan tanah marginal adalah jenis tanah ultisol. Luas ultisol di Indonesia mencapai 45,9 juta ha atau $24,3 \%$ dari daratan Indonesia (Subagyo et al., 2000). Ultisol merupakan salah satu jenis tanah marginal yang berpotensi untuk dimanfaatkan sebagai lahan pertanian.

Tanah ultisol mempunyai porositas , laju infiltrasi dan permeabilitas tanah rendah sehingga kemampuan untuk menahan air juga rendah. Selain itu tanah ultisol juga mempunyai kandungan $\mathrm{AL}$ dan $\mathrm{Fe}$ terlarut yang tinggi sehingga menyebabkan $\mathrm{pH}$ tanah menjadi rendah $(<5)$, kandungan bahan organik rendah yaitu $<1,15 \%$, kandungan hara rendah yaitu $\mathrm{N}$ berkisar $0,14 \%, \quad P$ sebesar 5,80 ppm, kejenuhan basa rendah yaitu $29 \%$ dan KTK juga rendah yaitu sebesar 12,6 me/100 g. (Soepardi 1994 dalam Naibaho 2018). Kondisi yang demikian menyebabkan tanaman yang dapat dibudidayakan sangat terbatas. Untuk meningkatkan kandungan unsur hara dan memperbaiki sifat tanah pada tanah ultisol dapat dilakukan dengan menambahkan bahan organik.

Kompos berperan sebagai soil conditioner dalam pembentukan agregat tanah atau berperan sebagai granulator (pembentukan struktur tanah berbentuk granular) yang menyebabkan struktur tanah menjadi gembur, mudah diolah dan mempunyai pori-pori yang cukup untuk kandungan air dan udara tanah (Alibasyah, 2016).
Pemberian bahan organik ke dalam tanah dapat meningkatkan cadangan total bahan organik tanah. Pemberian kompos kulit buah kakao diharapkan dapat memperbaiki sifat fisik tanah dan meningkatkan kesuburan tanah. Kompos kulit buah kakao berpotensi sebagai sumber bahan organik yang mempunyai peran penting dalam memperbaiki, meningkatkan dan mempertahankan produktivitas lahan secara berkelanjutan. Kompos kulit kakao mempunyai kandungan hara yang cukup tinggi terutama kalium dan nitrogen serta meningkatkan porositas tanah sehingga dapat memperbaiki aerasi dan drainase tanah serta meningkatkan aktivitas mikroorganisme tanah (Novizan, 2002 dalam Naibahu 2017).

Unsur hara yang terdapat dalam kulit buah kakao adalah $1,81 \% \mathrm{~N}, 26,61 \%$ COrganic, 0,31\% P2O5, 6,08\% K2O, 1,22\% $\mathrm{CaO}, 1,37 \% \mathrm{MgO}$ dan $44,85 \mathrm{cmol} / \mathrm{kg} \mathrm{KTK}$. Penggunaan kompos kulit kakao dapat meningkatkan produksi kakao hingga 19,48 \% (Gunadi, 2000 dalam Saragih, dkk,. 2017).

\section{METODE}

\subsection{Alat dan Bahan}

Alat yang digunakan dalam penelitian ini adalah cangkul, $\mathrm{pH}$ meter, timbangan digital, leaf area meter, dan oven, sedangkan bahan yang digunakan adalah benih kedelai varietas Dena 1 yang diperoleh dari BALITKABI Malang, kompos kulit buah kakao, tanah ultisol yang diambil dari gunung kidul, dan polybag dengan ukuran $25 \times 30 \mathrm{~cm}$.

\subsection{Metode}

Penelitian ini dilaksanakan di Dusun Soboman, Ngestiharjo, Kasian, Bantul, Yogyakarta pada bulan Juni - September 2019. Rancangan yang digunakan dalam penelitian ini adalah Rancangan Acak Lengkap dengan faktor tunggal yang diulang sebanyak tiga ulangan. Faktor tersebut adalah kompos kulit buah kakao yang terdiri dari 7 aras yaitu $(0,50,100,150,200,250$ dan 300) $\mathrm{gr} /$ tanaman. Setiap perlakuan terdiri atas 10 polybag sehingga terdapat 210 polybag.

Variabel yang diamati meliputi jumlah bintil akar, berat kering bintil akar, panjang akar, berat kering akar, luas daun, berat segar tanaman, berat kering tanaman, jumlah 
Agrisaintifika

Jurnal Ilmu-Ilmu Pertanian

Vol. 3, No. 2, 2019

Kusumastuti, dkk. 2019

polong isi per tanaman, bobot biji per tanaman dan indeks panen. Data hasil pengamatan dianalisis menggunakan ANOVA dan diuji lanjut dengan menggunakan Duncan's Multiple Range Test (DMRT) pada jenjang nyata $5 \%$ (Gomez, et al, 2007)

\section{HASIL DAN PEMBAHASAN}

Data hasil penelitian dianalisis dengan menggunakan analisis of varian dan untuk mengetahui beda nyata antar perlakuan dilakukan uji lanjut dengan menggunakan uji jarak berganda Duncan atau Duncan's Multiple Range Test (DMRT) pada jenjang nyata $5 \%$.

Hasil analisis menunjukkan bahwa pemberian kompos kulit buah kakao (KKBK) berpengaruh nyata terhadap jumlah dan berat kering bintil akar serta panjang dan berat kering akar.

Tabel 1. Rerata jumlah bintil akar, berat kering bintl akar, panjang akar dan berat kering akar

\begin{tabular}{ccccc}
$\begin{array}{c}\text { Perlakuan } \\
\text { (g)tanaman) }\end{array}$ & $\begin{array}{c}\text { Jumlah } \\
\text { Bintil Akar }\end{array}$ & $\begin{array}{c}\text { Berat Kering } \\
\text { Bintil Akar }\end{array}$ & Panjang Akar & Berat Kering Akar \\
\hline 0 & $11,28 \mathrm{~b}$ & $0,24 \mathrm{c}$ & $14,05 \mathrm{~b}$ & $1,23 \mathrm{~d}$ \\
50 & $11,87 \mathrm{~b}$ & $0,24 \mathrm{c}$ & $14,87 \mathrm{~b}$ & $1,38 \mathrm{~d}$ \\
100 & $12,18 \mathrm{~b}$ & $0,24 \mathrm{c}$ & $22,79 \mathrm{a}$ & $2,80 \mathrm{c}$ \\
150 & $12,32 \mathrm{~b}$ & $0,25 \mathrm{bc}$ & $20,90 \mathrm{a}$ & $4,48 \mathrm{~b}$ \\
200 & $13,20 \mathrm{ab}$ & $0,33 \mathrm{ab}$ & $22,40 \mathrm{a}$ & $6,09 \mathrm{a}$ \\
250 & $15,14 \mathrm{a}$ & $0,34 \mathrm{a}$ & $23,96 \mathrm{a}$ & $5,56 \mathrm{a}$ \\
300 & $15,10 \mathrm{a}$ & $0,38 \mathrm{a}$ & $23,20 \mathrm{a}$ & $6,12 \mathrm{a}$ \\
\hline Keterangan: Nilai yang dikuti huruf sama dalam kolom yang sama tidak berbeda \\
\multicolumn{5}{c}{ nyata pada Uji Jarak Berganda Duncan a $=5 \%$. }
\end{tabular}

Bintil akar merupakan hasil simbosis antara Rhizobium dengan tanaman inang yang mampu menambat $\mathrm{N} 2$ dari udara. Bakteri Rhizobium dapat bersimbosis hanya dengan tumbuh-tumbuhan legum, dengan menginfeksi akarnya dan membentuk bintil akar di dalamnya (Rao, 1994 dalam Sari R, dkk. 2018).

Pemberian kompos kulit buah kakao dengan dosis $300 \mathrm{~g} /$ tanaman menghasilkan jumlah dan berat kering bintil akar tertinggi tetapi tidak berbeda nyata dengan dosis 200 dan $250 \mathrm{~g} /$ tanaman (tabel 1).

Ketersediaan unsur hara selama proses pembintilan mutlak dibutuhkan. Kompos kulit buah kakao banyak mengandung berbagai unsur hara esensial seperti nitrogen dan fosfor, dimana kedua unsur hara tersebut sangat berpengaruh dalam proses pembentukan bintil akar. Fosfor mampu meningkatkan jumlah bintil akar yang terbentuk Yakubu, dkk; (2010).

Pemberian bahan organik seperti kompos mampu mempengaruhi pertumbuhan sistem perakaran pada tanaman. memperbaiki sifat fisik tanah, struktur menjadi remah sehingga memungkinkan pertumbuhan akar lebih cepat.

Struktur tanah yang padat akan menghambat laju penetrasi akar lebih dalam karena tanah padat susah ditembus akar, maka daerah pemanjangan akar semakin pendek. Tanah yang memiliki tingkat kepadatan tinggi total panjang akarnya rendah. Kepadatan tanah meningkat maka ruang pori makro menurun dan penetrasi akar dihambat. Pertumbuhan akar yang terhambat pada tingkat kepadatan tanah yang tinggi dapat dilihat pada berat kering akarnya (Russel, 1977 dalam Rusdiana, dkk; 2000).

Pemberian kompos kulit buah kakao dengan dosis $250 \mathrm{~g} /$ tanaman menghasilkan akar terpanjang yaitu 23, 96 tetapi tidak berbeda nyata dengan dosis 100, 150, 200 dan $300 \mathrm{~g} /$ tanaman (Tabel 1.) Hal ini menunjukkan bahwa pemberian dosis kompos kulit buah kakao yang paling efektif adalah 100 gr/tanaman dikarenakan dengan penambahan selisih dosis yang diberikan tidak berbeda nyata dengan perlakuan dosis $300 \mathrm{gr} / \mathrm{tanaman}$.

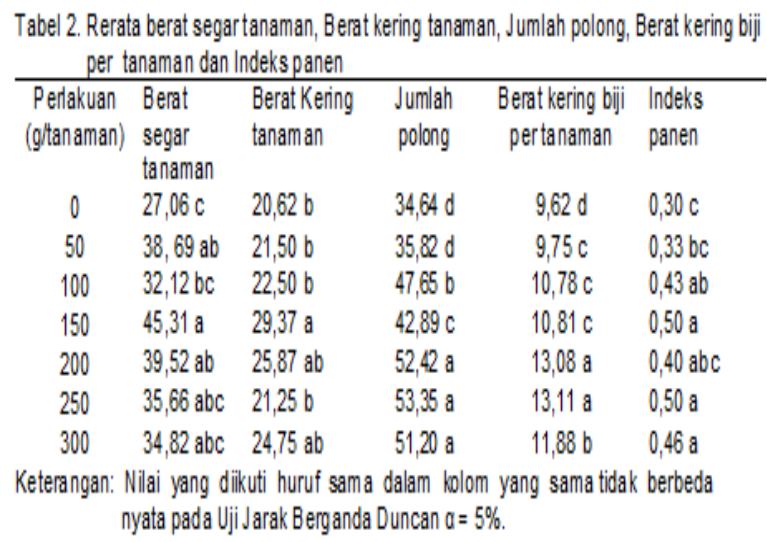

Selain berpengaruh terhadap pertumbuhan akar, pemberian kompos kulit buah kakao juga berpengaruh nyata terhadap berat kering dan berat basah tanaman. Pemberian kompos dengan dosis 150 $\mathrm{g} /$ tanaman memberikan berat segar dan berat kering tanaman tertinggi dan tidak berbeda 
nyata dengan pemberian dosis 200,250 dan $300 \mathrm{~g} /$ tanaman (Tabel 2.).

Pemberian bahan organik berupa kompos di dalam tanah dapat menambah ketersediaan unsur hara yang diperlukan oleh tanaman sehingga dapat meningkatkan pertumbuhan dan perkembangan tanaman. Brata dan Nelistya (2008) dalam Widodo, dkk (2018) menjelaskan bahwa bahan organik berfungsi untuk meningkatkan kesuburan tanah dan menyimpan unsur hara yang secara perlahan disediakan untuk tanaman.

Jumlah polong dan berat kering biji per tanaman tertinggi diperoleh dari pemberian kompos kulit buah kakao dengan dosis 200 g/tanaman (Tabel 2.). Dalam kompos kulit buah kakao terkandung berbagai unsur hara baik makro ataupun mikro diantaranya adalah unsur K. Unsur K pembentukan polong dan polong bernas pada tanaman kedelai. Semakin tinggi $\mathrm{K}$ maka pembentukan dan pengisian polong akan berjalan secara optimal (Hanibal, 1995) dalam Wahyudin, dkk (2017). Selain itu Unsur K juga diperlukan oleh tanaman untuk pembentukan gula dan zat tepung serta mengaktifkan berbagai enzim.

Hasil bobot biji per tanaman dipengaruhi oleh fotosintesis, dimana proses ini dipengaruhi oleh unsur hara N,P,K. Unsur hara $\mathrm{N}$ berperan penting sebagai penyusun protein yang akan digunakan oleh tanaman untuk meningkatkan jumlah polong isi.

Unsur fosfor berperan dalam Suplay dan transfer energi pada semua proses fisiologis tanaman sebagai contoh adalah membantu mempercepat proses perkembangan dan pemasakan polong sehingga menghasilkan bobot biji yang tinggi (Rochman dan Sugiyanta, 2007).

Indeks panen menggambarkan distribusi bahan kering dalam tanaman yang menunjukkan perimbangan bobot bahan kering yang bernilai ekonomis dengan total bobot bahan kering tanaman pada saat panen. Nilai indeks panen yang tinggi berarti bahwa tanaman mampu mendistribusikan asimilat lebih banyak ke dalam polong. Nilai indeks panen tertinggi diperoleh pada pemberian kompos dengan dosis 150 g/tanaman (Tabel 2.)

Pemberian bahan organik sampai dosis tertentu meningkatkan indeks panen karena dapat meningkatkan hasil ekonomi berupa bobot biji (Rahni, 2012). Peningkatan hasil panen berupa biji terutama disebabkan oleh peningkatan indeks panen. Dengan kata lain, tanaman yang tidak lagi memproduksi bobot kering total, tetapi lebih banyak membagi bobot keringnya ke hasil panen.

\section{SIMPULAN}

Berdasarkan hasil penelitian tentang pemberian kompos kulit buah kakao pada tanah ultisol dapat disimpulkan bahwa pemberian kompos kulit buah kakao dengan dosis $150 \mathrm{~g} /$ tanaman tingkat efisiensinya lebih tinggi dan mampu mempengaruhi pertumbuhan dan hasil tanaman kedelai. Pemberian kompos kulit buah kakao sebagai bahan organik mampu memperbaiki sifat fisik tanah dan meningkatkan ketersediaan unsur hara pada tanah ultisol sehingga produktivitasnya lebih meningkat.

\section{DAFTAR PUSTAKA}

Alibasyah R., 2016. Perubahan Beberapa Sifat Fisika Dan Kimia Ultisol Akibat Pemberian Pupuk Kompos Dan Kapur Dolomit Pada Lahan Berteras. J. Floratek 11 (1): 75-87.

Naibaho, J., Nelvia dan A.I.Amri. 2017. Pemberian Kompos Kulit Buah Kakao Pada Medium Ultisol untuk Pertumbuhan Bibit Kakao (Theobroma cacao, L) JOM FAPERTA, Vol 4 No. 2.

Rahni, N.M. 2012. Efek FitohormonTerhadap Pertumbuhan Tanaman Jagung (Zea mays). Artikel Dosesn Agroteknologi. Universitas Haluoleo.

Riniarsi, D. 2015. Outlook Komoditas Pangan. Kedelai. Pusat Data dan Sistem Informasi Pertanian, Kementrian Pertanian.

Rochman, H.F dan Sugiyanta. 2007. Pengaruh Pupuk Organik dan Anorganik terhadap Pertumbuhan 
Kusumastuti, dkk. 2019

dan Hasil Padi Sawah (Oryza Sativa L.). Jurnal. Bogor. IPB.

Rusdiana O, Y Fakura, Kusmana C dan Hidayat Y., $2000 . \quad$ Respon Pertumbuhan Akar Tanaman Sengon (Paraserianthes falcataria) Terhadap Kepadatan Dan Kandungan Air Tanah Podsolik Merah Kuning. Jurnal Manajemen Hutan Tropika Vol. 6 No. $2: 43-53$.

Saragih. D. P dan Ardian, 2017. Pengaruh Pemberian Kompos Kulit Buah kakao terhadap Pertumbuhan Bibit kakao Hibrida (Theobroma cacao L). JOM FAPERTA Vol 4 No 2.

Sari, R dan R Prayudtaningsih,. 2018. Perkembangan Bintil Akar pada Sengon Laut (Paraserianthes falcataria (L) Nielsen). Info Teknis Eboni Vol 15 No 2: 105-119.

Subagyo, H., N. Suharta dan A. B. Siswanto. 2004. Tanah-Tanah Pertanian di Indonesia. Bogor : Pusat Penelitian Tanah dan Agriklimat. Hal $21-66$. Wahyudin, A. · F.Y. Wicaksono · A.W. Irwan - Ruminta, - R. Fitriani, 2017. Respons Tanaman Kedelai (Glycine max) Varietas Wilis Akibat Pemberian Berbagai Dosis Pupuk N, P, K, dan Pupuk Guano Pada Tanah Inceptisol Jatinangor. Jurnal Kultivasi Vol. 16(2): $333-339$.

Widodo, K.H dan Z. Kusuma. 2018. Pengaruh Kompos terhadap Sifat Fisik Tanah dan Pertumbuhan Tanaman Jagung di Inceptisol. Jurnal Tanah dan Sumberdaya Lahan Vol 5 No 2 : 959967.

Yakubu, H., J.D. Kwari and M.K. Sandabe. 2010. Effect of Phosphorus Fertilizer on Nitrogen Fixation by Some Grain Legume Varieties in Sudan Sahelian Zone of North Eastern Nigeria. Nigerian Journal of Basic and Applied Science 18(1):19-26. 